\title{
AN ANALYSIS AND IMPROVEMENT OF THE PRODUCTION PROCESS OF EXTERNAL DOORS
}

\begin{abstract}
The study aimed to conduct a cost-value analysis of the production process of a newly introduced batch of external doors in the context of value-added creation and to identify redundant processes that do not create added value and for which appropriate corrective actions could contribute to their elimination. The result of applying improvement actions following the lean management concept was the optimization time nationalized analyzed by eliminating, among others, operations related to unnecessary transport and storage of products. In addition, the optimization production process impacted both shortening the process implementation time and reducing the costs of its implementation. Further activities will be related to the use of the presented methodology to analyze the processes implemented in the company in order to increase their efficiency.
\end{abstract}

Keywords: quality, cost, production engineering, improvement.

\section{INTRODUCTION}

The need for improvement in companies has been around for a long time, but in today's rapidly changing marketplace, it has become essential (Liker and Franz, 2013; Womack and Jones, 2012; Ostasz et. al., 2020; Mentel and Hajduk-Stelmachowicz, 2020; Wolniak and Skotnicka, 2008). The requirement to be a flexible, efficient, growth-oriented enterprise and adapt quickly to a changing environment indicates the primary rationale for pursuing excellence and remaining competitive. Improvement can cover various aspects of the company, for example, processes, activities, products and services (Wolniak, 2013; Alinejad and Anvari, 2019; Lim et. al., 2019; Pacana et al., 2019).

Currently, many enterprises use the process approach in management because the identification of processes occurring in the organization deepens and interprets the creation of added value, while their improvement increases the efficiency of implementation and the level of the buyers' satisfaction (Lichtarski, 2015; Van Looy, 2021; Zuhaira and Ahmad 2021). Companies implement various methods and management concepts that use a process approach, for example, TQM (Total Quality Management) (Permana et. al., 2021; Lasrado

\footnotetext{
${ }^{1}$ Karolina Czerwińska, MSc, Rzeszow University of Technology, Rzeszów, 12 Powstańców Warszawy Ave., 35-959 Rzeszów; e-mail: k.czerwinska@ prz.edu.pl (corresponding author). ORCID: 0000-0003-1121-6352.

2 Michalene Eva Grebski, PhD, Colorado Mesa University, 1100 North Avenue, Grand Junction, CO 81504 USA; e-mail: mgrebski@ coloradomesa.edu. ORCID: 0000-0002-3487-4473.
} 
and Nyadzayo, 2020; Tasleem et. al., 2016); Lean Management (Moyano-Fuentes et. al., 2021; Maldonado et. al., 2020), Six Sigma (Simanova and Gejdos, 2021; Raval et. al., 2020). Quality Management System (QMS) according to ISO standards (Sfreddo et. al., 2021; Pacana and Ulewicz, 2020). Moreover, companies seek additional benefits through their integration (Montgomery, 2013; Soare, 2012; Salah et. al., 2010; Sa et al., 2020; Youssef and Youssef, 2018). Their practices indicate the need to implement a multi-step process of process improvement and mechanisms to support their improvement and management. Essential support in the context of process improvement is the provision of adequate human resources who will be able to effectively manage and improve the processes (Bessant et. al., 2001; Yen-Tsang et. al., 2015).

The study aimed to carry out a cost-value analysis of the production process of a newly introduced batch of external doors in the context of value-added creation and to identify redundant processes that do not create added value and for which appropriate corrective actions could contribute to their elimination.

\section{SCOPE AND SUBJECT MATTER}

Due to a decrease in efficiency, the desire to reduce costs of the production process and the desire to implement improvements, the research subject was the production process of a newly implemented product - external doors. The survey was conducted in Q4 2019. in one of the manufacturing companies (Erkado) located in the southern part of Poland.

\section{RESEARCH METHODOLOGY}

In the study, it was decided to identify the structures of individual categories of the production process of external doors, which is a determinant of the effects of its Implementation, which (in addition to its primary purpose) include the creation of added value for customers. The methodology of process analysis in terms of value-added generation used in this study is presented in Figure 1.

The implementation of process evaluation in the context of value-added starts with answering two fundamental questions, "Can the process be eliminated without compromising the benefits achieved by the customer?" and "Can the process be eliminated without compromising the cooperating processes?". If both questions are answered in the negative, it means that we are dealing with a process directly related to the creation of added value. However, if the answer is yes, it is likely that the process does not create added value. However, not all processes that do not directly add value are processes that need to be removed.

On the other hand, negative answers prove that the analysis is not related to the creation of added value - these are unnecessary processes. This type of activity adversely affects the process as it generates additional costs and increases the process time. 


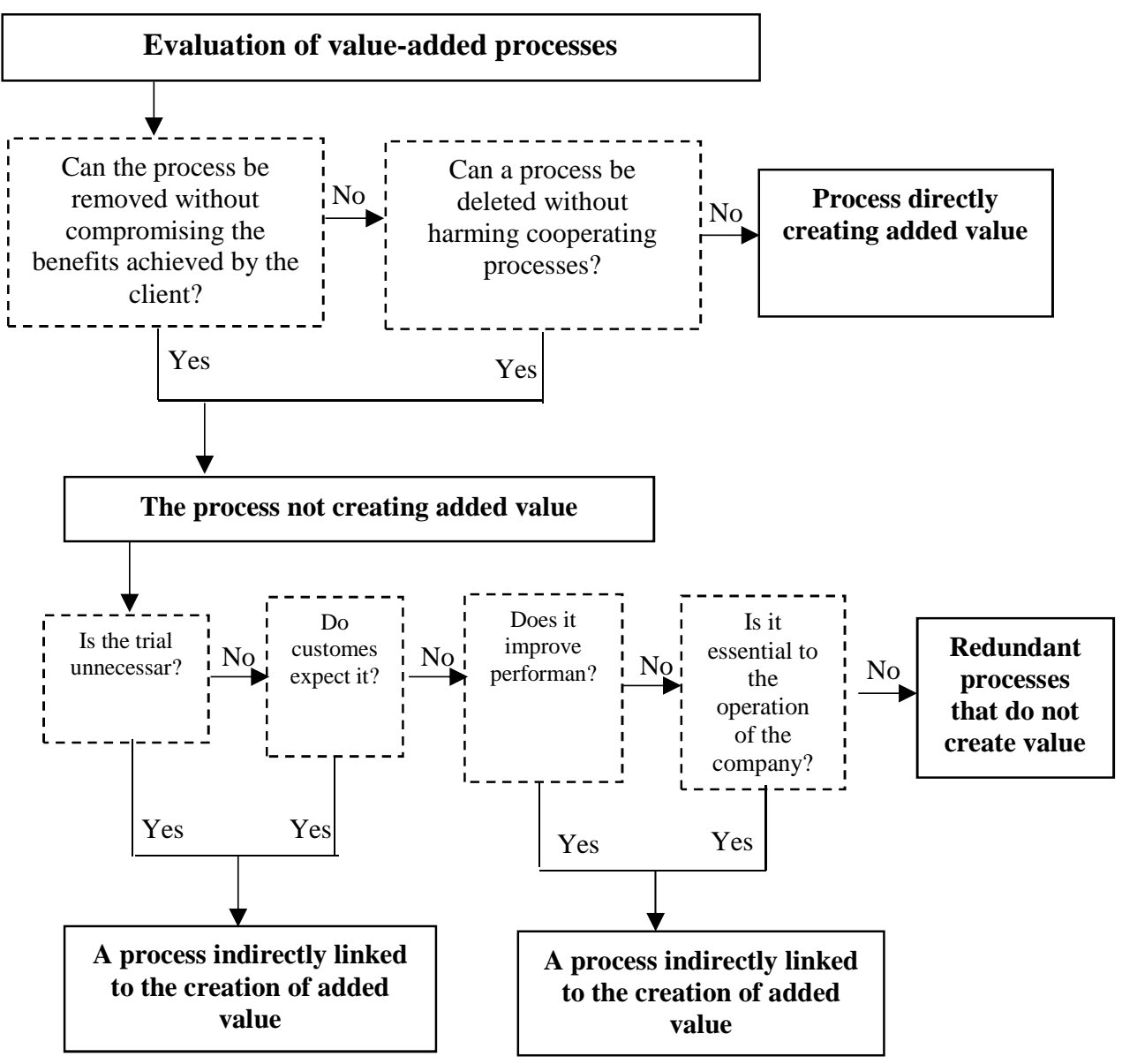

Figure 1. Algorithm for evaluating processes in the context of creating added value

Source: Own study based on: (Kulińska, pdf).

\section{RESULTS AND DISCUSSION}

The analyzed process of external doors along with the division of operations into operations creating added value (1), operations not creating added value but necessary to produce the product (2) and redundant operations - not creating added value (3) are presented in Table 1. The second group of the breakdown of operations includes operations indirectly creating value-added and those relatively related to value creation.

The production process of the studied product was analyzed for the duration of individual operations and the creation of added value. The analysis showed that the manufacturing process consists of 32 operations with 7 hours, 31 minutes and 5 seconds. Among all operations, only 22 create added value and their execution time is 1 hour and 38 minutes. Six operations do not add value to the manufactured product. The most extended 
operations in this group include storage of the finished product and marking. The duration of the most extended operation is related to the time after which the stored items will be transferred to an external customer.

Table 1. Exterior door process chart

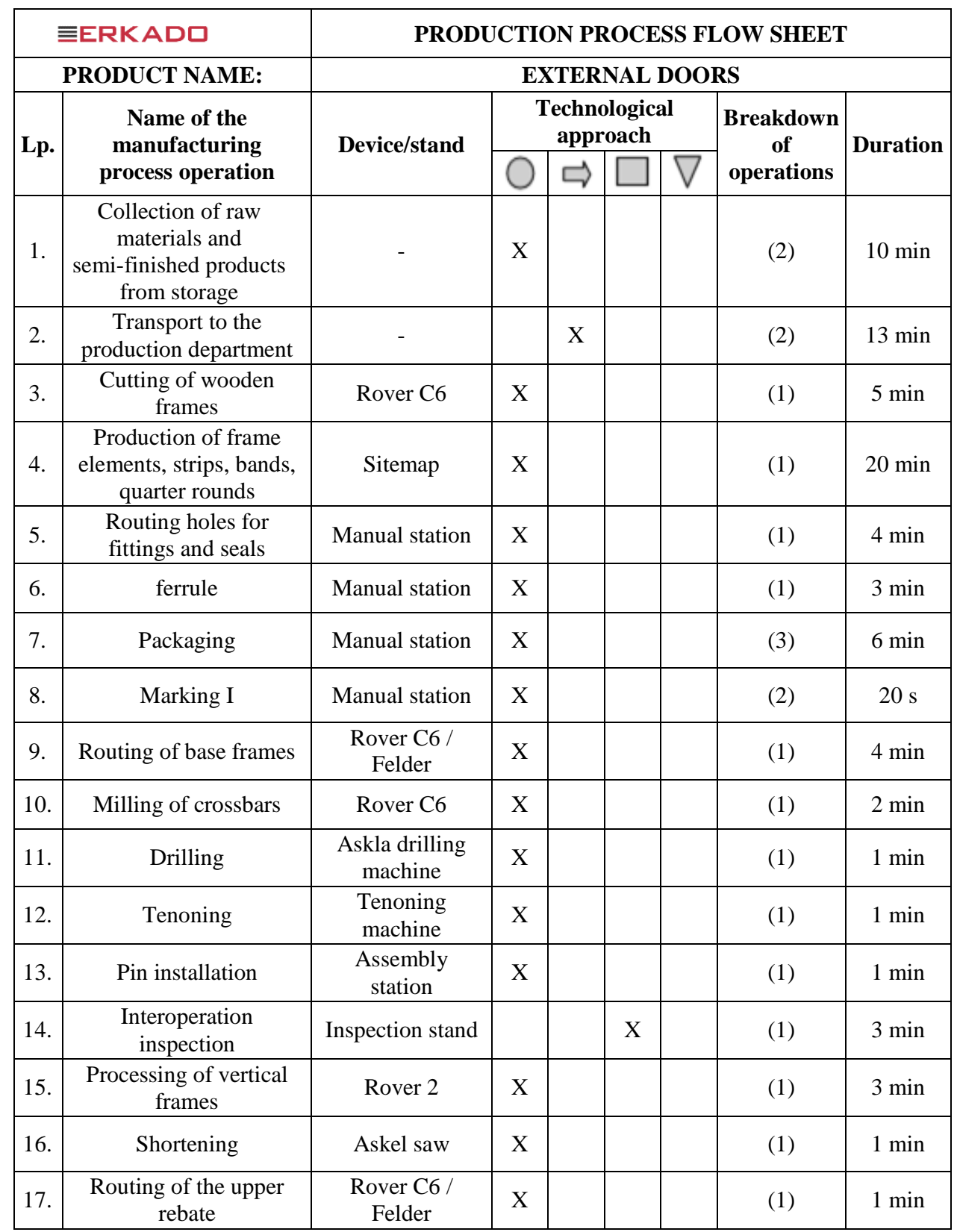


Table 1 (cont.). Exterior door process chart

\begin{tabular}{|c|c|c|c|c|c|c|c|c|}
\hline \multirow{2}{*}{\multicolumn{2}{|c|}{$\begin{array}{l}\text { 三ERKADD } \\
\text { PRODUCT NAME: }\end{array}$}} & \multicolumn{7}{|c|}{ PRODUCTION PROCESS FLOW SHEET } \\
\hline & & \multicolumn{7}{|c|}{ EXTERNAL DOORS } \\
\hline \multirow{2}{*}{ Lp. } & \multirow{2}{*}{$\begin{array}{l}\text { Name of the } \\
\text { manufacturing } \\
\text { process operation }\end{array}$} & \multirow{2}{*}{ Device/stand } & \multicolumn{4}{|c|}{$\begin{array}{l}\text { Technological } \\
\text { approach }\end{array}$} & \multirow{2}{*}{$\begin{array}{c}\text { Breakdown } \\
\text { of } \\
\text { operations }\end{array}$} & \multirow{2}{*}{ Duration } \\
\hline & & & & $\Rightarrow$ & $\square$ & $\nabla$ & & \\
\hline 18. & $\begin{array}{c}\text { Drilling holes for } \\
\text { dowels, hinges and lock }\end{array}$ & $\begin{array}{l}\text { Askla drilling } \\
\text { machine }\end{array}$ & $\mathrm{X}$ & & & & (1) & $4 \min$ \\
\hline 19. & Marking II & Tunnel & $\mathrm{X}$ & & & & (3) & $20 \mathrm{~s}$ \\
\hline 20. & Receiving inspection & Inspection stand & & & $\mathrm{X}$ & & $(1)$ & $5 \mathrm{~min}$ \\
\hline 21. & $\begin{array}{l}\text { Arrangement on } \\
\text { transport racks }\end{array}$ & Tunnel & $\mathrm{X}$ & & & & $(2)$ & $3 \mathrm{~min}$ \\
\hline 22. & $\begin{array}{l}\text { Selection of elements } \\
\text { (crossbars, vertical } \\
\text { frames, glass) }\end{array}$ & $\begin{array}{l}\text { Position. } \\
\text { assembly }\end{array}$ & $\mathrm{X}$ & & & & (2) & $4 \min$ \\
\hline 23. & $\begin{array}{c}\text { Installation of } \\
\text { waterproof plywood }\end{array}$ & $\begin{array}{l}\text { Edge banding } \\
\text { machine }\end{array}$ & $\mathrm{X}$ & & & & (1) & $6 \mathrm{~min}$ \\
\hline 24. & Filing & $\begin{array}{l}\text { Position. } \\
\text { assembly }\end{array}$ & $\mathrm{X}$ & & & & (1) & $3 \min$ \\
\hline 25. & $\begin{array}{l}\text { Polyurethane foam } \\
\text { padding }\end{array}$ & Manual station & $\mathrm{X}$ & & & & (1) & $12 \min$ \\
\hline 26. & Ironing & Diaphragm press & $X$ & & & & $(1)$ & $10 \mathrm{~min}$ \\
\hline 27. & Fitting of fittings & $\begin{array}{l}\text { Position. } \\
\text { assembly }\end{array}$ & $\mathrm{X}$ & & & & (1) & $2 \min$ \\
\hline 28. & Quality Control & Inspection stand & & & $\mathrm{X}$ & & $(1)$ & $4 \mathrm{~min}$ \\
\hline 29. & Packaging & Tunnel & $X$ & & & & $(1)$ & $5 \min$ \\
\hline 30. & Marking III & Tunnel & $X$ & & & & (3) & $25 \mathrm{~s}$ \\
\hline 31. & $\begin{array}{l}\text { Transport to finished } \\
\text { goods warehouse }\end{array}$ & - & & $\mathrm{X}$ & & & (3) & $15 \mathrm{~min}$ \\
\hline 32. & Storage & Magazine & & & & $\mathrm{X}$ & (3) & Five h. \\
\hline
\end{tabular}

Source: Own study.

In order to assess the added value in the examined process, the costs of particular operations were estimated. Then the dependence between the cost of operation (WK) and the adopted indicator Wkw were identified. The indicator used determines the relation between the costs and the product's value. (The value of the product means the price the buyer pays for a particular product.) The result of the analysis is shown in Figure 2. The chart shows the value chain of the production process, including the $\mathrm{WKW}$ and $\mathrm{WK}$ indicators expressed in percentage.

In Figure 2, Group 1 refers to activities that are part of the process and add value. Group 2 refers to operations that do not add value but are necessary to be performed. Group 3 refers to operations that are redundant and do not add value. 


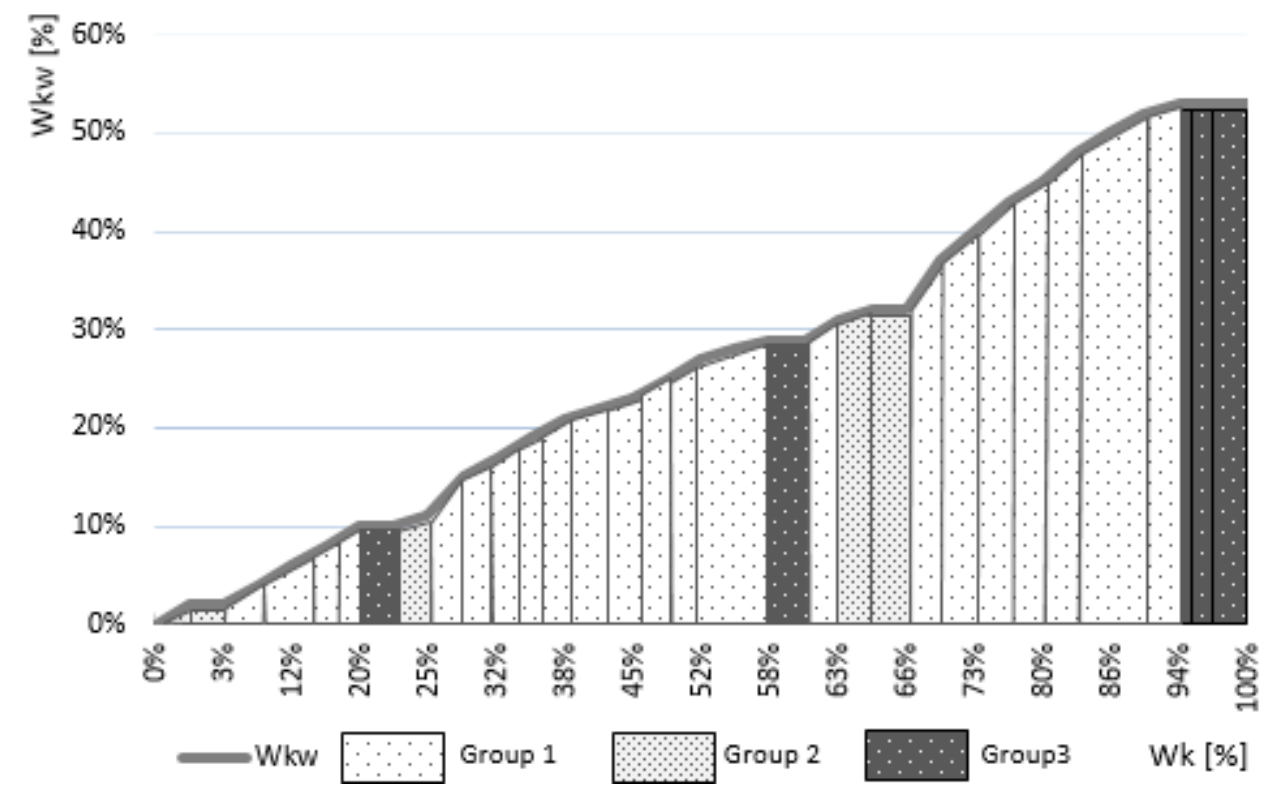

Figure 2. Diagram of the creation of added value of the analyzed process

Source: Own study.

As part of further analysis of the process, a summary of the lead times for non-valueadded operations was compiled (Table 2).

Table 2. Summary of the duration of non-value-added operations

\begin{tabular}{|c|c|c|}
\hline Technological operation & Time for one $[\mathbf{h}]$ & Time for a batch of $\mathbf{7 0}[\mathbf{h}]$ \\
\hline Packaging & 0.1 & 7 \\
\hline Signage & 0.0125 & 0.875 \\
\hline Transport & 0.25 & 17.5 \\
\hline Storage & 5 & 350 \\
\hline Total & $\mathbf{5 . 3 6 2 5}$ & $\mathbf{3 7 5 . 3 7 5}$ \\
\hline
\end{tabular}

Source: Own study.

The data in Table 2 show a large share of warehousing time compared to other nonvalue-added operations. Therefore, as part of the activities to minimize inefficiencies in warehousing, management under the just-in-time method were implemented. This method involves the complete elimination of waste by supplying each production process with all the required items at the required time and in the required quantity.

Based on the analysis (Table 2), it can be seen that a significant amount of time is also consumed by transport (of materials to the production hall and transport to the warehouse). Therefore, the remedial actions used a methodology consistent with the concept of Lean Manufacturing. Furthermore, when designing the new production line, the issue of the speed of the flow of the machined elements of the product was taken into consideration by 
appointing a streamline, which, according to its essence, eliminates excessive transport between the production halls. In addition, actions have been taken to restructure the organizations themselves, allowing them to reduce transport time between workstations and eliminate "packing operations".

Although it does not generate high costs, after more analysis, the issue of product marking was decided that the operation Marking II and Marking III are unnecessary. Instead of creating new labels, it was decided to adopt the labels from operation "Labelling I" to include additional information.

The implementation of improvement actions contributed to the elimination of redundant operations in the analysis. Additionally, thanks to the reorganization of the production line and workstations, the execution time of operations that do not create added value but are necessary for the realization process was reduced (Table 3 ).

Table 3. Summary of the duration of non-value added operations after implementation of improvement actions

\begin{tabular}{|c|c|c|}
\hline Technological operation & Time for one [h] & Time for a batch of 70 [h] \\
\hline Packaging & 0 & 0 \\
\hline Signage & 0,005 & 0.35 \\
\hline Transport & 0.083 & 5.81 \\
\hline Storage & 0 & 0 \\
\hline Total & $\mathbf{0 . 0 8 8}$ & $\mathbf{6 . 1 6}$ \\
\hline
\end{tabular}

Source: Own study.

The presented times of non-value-creating operations in Table 2 and Table 3 indicate the success of the implemented improvement actions. Because of their implementation, the operation time per batch of 70 products decreased by $98.35 \%$, which is also associated with a decrease in the finished product cost.

\section{SUMMARY AND CONCLUSION}

The foundation of production process improvement is the effective connection and use of production elements resulting from the need to meet customer requirements, increase competitiveness, increase the essence of flexibility, both internal and external. The quality of the processes also depends mainly on the modernity of the product and the organizational organization applied in the company.

Among the many possibilities of improving the organization, activities related to increasing the effectiveness of implemented processes play an important role. therefore, it seems reasonable to undertake cost-value analysis of the main processes in manufacturing companies. The aim of the research was to perform a cost-value analysis of the production process in relation to the newly introduced batch of external doors within the framework of creating added value and to identify unnecessary processes that do not create added value and in relation to which appropriate corrective actions could contribute to their elimination. The study optimised the production process of external doors in terms of creating added value. Because of the implementation of improvement actions in accordance with the Lean Management concept, the time of some operations, which do not create added value but are necessary to carry out the process, was reduced and unnecessary operations, which did not 
create added value, were eliminated. Moreover, the implemented improvements reduced the costs of process execution, increasing the efficiency of the process and the timeliness of task completion.

The proposed cost-value analysis is a useful and effective way of analyzing processes, which can be practised in various enterprises.

Further research directions will concern the analysis of other production processes in the investigated enterprise.

\section{REFERENCES}

Alinejad, A., Anvari, A. (2019). The Mediating Effect of Collaborative Structure and Competitive Intensity on the Relationship between Process Management and Organization Performance. "Iranian Journal of Management Studies”, V. 12, I. 1.

Bessant, J., Caffyn, S., Gallagher, M. (2001). An evolutionary model of continuous improvement behaviour. "Technovation", V. 21, No. 1.

Kulińska E., Wartość dodana $w$ procesach logistycznych, http://www.ptzp.org.pl/files/ konferencje/kzz/artyk_pdf_2009/074_Kulinska.pdf (access: 01.09.2021).

Lasrado, F., Nyadzayo, M. (2020). Improving service quality Examining the drivers and outcomes of TQM internalization in organizations. "Journal of Quality \& Reliability Management”, V. 37, I. 3.

Lichtarski, J. (2015). Praktyczny wymiar nauk o zarzadzaniu. Warszawa: PWE.

Liker, J. K., Franz, J. K. (2013). Droga Toyoty do ciagłego doskonalenia, tłum. D. Gasper. Warszawa, MT Biznes.

Lim, C., Kim, M. J., Kim, K. H., Kim, K. J., Maglio, P. (2019). Customer process management a framework for using customer-related data to create customer value. "Journal of Service Management”, V. 30, I. 1.

Maldonado, M. U., Leusin, M. E., Bernardes T. C. D., Vaz C. R. (2020). Similarities and differences between business process management and lean management. "Business Process Management Journal”, V. 26, I. 7.

Mentel U., Hajduk-Stelmachowicz M., (2020). Does standard standardization impact innovation activity in different countries? "Problems and Perspectives in Management", 18(4).

Montgomery D. (2013). Lean Six Sigma and Quality Management. "Quality and Reliability Engineering International", V. 29, I. 7.

Moyano-Fuentes J., Maqueira-Marin J. M., Martinez-Jurado P. J., Sacristan-Diaz, M. (2021). Extending lean management along the supply chain: impact on efficiency. "Journal of Manufacturing Technology Management”, V. 32, I. 1.

Pacana, A., Ulewicz, R. (2020). Analysis of causes and effects of Implementation of the quality management system compliant with ISO 9001. "Polish Journal of Management Studies", V. 21, I. 1 .

Pacana, A., Czerwińska, K., Bednarova, K. (2019). Comprehensive improvement of the surface quality of the diesel engine piston. "Metalurgija, Hrvatsko Metalursko Društvo" (HMD), 58(3-4).

Patel, A. S., Patel, K. M. (2021). Critical review of literature on Lean Six Sigma methodology. “International Journal of Lean Six Sigma”. DOI: 10.1108/IJLSS-04-2020-0043.

Permana, A., Purba, H. H., Rizkiyah, N. D. (2021). A systematic literature review of Total Quality Management (TQM) Implementation in the organizational. "Journal of Production Management and Engineering”, V. 9, I. 1. 
Raval S. J., Kant R., Shankar R. (2020). Analyzing Six Sigma enabled organizational performance to enhance operational efficiency. "Benchmarking-An International Journal", V. 27, I. 8.

Sa, J. C., Vaz, S., Carvalho, O., Lima, V., Morgado, L., Fonseca, L., Doiron, M., Santos, G. (2020). A model of integration ISO 9001 with Lean six Sigma and main benefits achieved. "Total Quality Management \& Business Excellence”. DOI: 10.1080/14783363.2020. 1829969.

Salah, S., Rahim A., Carretero, J.A. (2010). The integration of Six Sigma and lean management. "International Journal of Lean Six Sigma”, V. 1, I. 3.

Sfreddo, L. S., Vieira, G. B. B., Vidor, G., Santos, C. H. S. (2021). ISO 9001 based quality management systems and organizational performance: a systematic literature review. “Total Quality Management \& Business Excellence”, V. 32, I. 3-4.

Simonova, L., Gejdos, P. (2021), Implementation of the six sigma methodology in increasing the capability of processes in the company of the furniture industry of the Slovak republic. “Management Systems In Production Engineering”, V. 29, I. 1.

Soare, P. (2012). Opportunities for driving continuous improvement through TQM, Lean and Six Sigma within business process management. Proceedings of The 6th International Management Conference: Approaches In Organisational Management, Bukareszt, Romania.

Tasleem, M., Khan, N., Masood, S. A. (2016). Impact of TQM and Technology Management on Organizational Performance. "Mehran University Research Journal of Engineering And Technology", V. 35, I. 4.

Ustaz, G., Czerwińska, K., Pacana, A. (2020) Quality management of aluminium pistons with the use of quality control points, Management Systems in Production Engineering.

Van Looy, A. (2021), A quantitative and qualitative study of the link between business process management and digital innovation. "Information \& Management", V. 58, I. 2.

Wolniak, R. (2013). Metody i narzędzia lean production i ich rola $w$ ksztattowaniu innowacji w przemyśle [w:] Knosala, R., red., Innowacje w zarzadzaniu i inżynierii produkcji. Opole: Oficyna Wydawnicza Polskiego Towarzystwa Zarządzania Produkcją, Opole.

Wolniak, R., Skotnicka, B. (2008), Metody i narzędzia zarządzania jakościa, Teoria i praktyka. Gliwice: Wydawnictwo Politechniki Śląskiej.

Womack, J. P., Jones, D. T. (2012). Lean thinking - szczupte myślenie. Wrocław: ProdPublishing.

Yen-Tsang, Ch., Csillag J. M., Siegler J. (2012). Theory of Reasoned Action for continuous improvement capabilities: a behavioural approach, RAE Sao Paulo, Vol. 52, No. 5.

Youssef, M. A., Youssef, E. M. (2018). The synergistic impact of ISO 9000 and TQM on operational performance and competitiveness. "International Journal of Quality \& Reliability Management”, V. 35, I. 3.

Zuhair, B., Ahmad, N. (2021). Business process modeling, implementation, analysis, and management: the case of business process management tools. "Business Process Management Journal", V. 27, I. 1.

DOI: $10.7862 /$ rz.2021.mmr.17

The text was submitted to the editorial office: June 2021.

The text was accepted for publication: September 2021. 
